\title{
Beleid vir die hantering van beledigende en sensitiewe leksikale items in die Woordeboek van die Afrikaanse Taal.
} geformuleer deur

\section{P. Harteveld en A.E. van Niekerk, Buro van die Woordeboek van die Afrikaanse Taal, Stellenbosch, Suid-Afrika}

Abstract and Keywords: See the English version below.

Opsomming: Skema van die beleid vir die hantering van beledigende en sensitiewe leksikale items in die Woordeboek van die Afrikaanse Taal:

\section{Gemeenskaplik aan alle sensitiewe leksikale items}

- alle simplekse, komposita en uitdrukkings word gelemmatiseer

- almal voldoen aan die algemene gebruiklikheidskriterium van die Buro

- duidelike en juiste etikettering vind plaas, ook by kwetsende sinonieme

- die metataal is neutraal

- geen kollokasies en poëme word opgeneem nie

- sitate (waar wel gegee) word sensitief gekies

- artikels word deur toepaslike adviseurs gekontroleer

A. Rassismes

1. Hantering in die WAT

(a) Volledig rassistiese leksikale items

- definisie word gegee by die gebruiklikste neutrale sinoniem; geen rassistiese sinonieme word egter by 'n neutrale of rassistiese item opgeneem nie

- geen semantiese opposisies word gegee nie

- geen sitate word gegee nie

- uitdrukkings word verklaar; geen sinonieme, antonieme, verwysings en voorbeeldmateriaal word egter daarby gegee nie

- dieselfde hanteringswyse geld vir rassistiese uitdrukkings onder neutrale lemmas

- volledige bewerking geskied in elektroniese vorm (sien 2 hier onder)

Hierdie beleid is deur die Beheerraad van die Buro van die WAT goedgekeur as sy amptelike beleid vir die hantering van beledigende en sensitiewe leksikale items in die Woordcboek van die Afrikaanse Taal. Die Buro van die WAT ontvang graag kommentaar op hierdie dokument. 
(b) Gedeeltelik rassistiese leksikale items

- neutrale betekenisonderskeidings word volledig bewerk

- rassistiese betekenisonderskeidings en uitdrukkings word behandel soos volledig rassistiese leksikale items

2. Hantering in die elektroniese manuskrip

- sinoniemverwysings, sinoniemvermeldings en semantiese opposisies word gegee

- sitate word gegee

- elektroniese manuskrip is op aanvraag beskikbaar

B. Seksismes en sensitiewe leksikale items wat gestigmatiseerde seksuele verskynsels, praktyke en voorkeure by die mens aandui

- die definisie kom by die gebruiklikste neutrale sinoniem

- sinoniemverwysing en sinoniemvermelding vind plaas

- antonieme en formele verwysings word gegee

- sitate word gegee

- uitdrukkings word verklaar

C. Sensitiewe leksikale items wat gestigmatiseerde fisieke of geestelike toestande en verskynsels by die mens aandui

- bewerking vind plaas soos onder B hier bo

D. Sensitiewe leksikale items binne 'n sosiale, politieke en godsdienstige struktuur

- bewerking vind plaas soos onder $B$ hier bo

E. Plat en vulgère leksikale items, skeltaal en vloeke

- bewerking vind plaas soos onder $B$ hier bo

Sleutelwoorde: BELED, HANTERING, BELEDIGENDE LEKSIKALE ITEMS, SENSITIEWE LEKSIKALE ITEMS, WOORDEBOEK, WOORDEBOEK VAN DIE AFRIKAANSE TAAL, SIMPLEKSE, KOMPOSITA, UITDRUKKINGS, ALGEMENE GEBRUIKLIKHEDSKRITERIUM, ETIKETTERING, SINONIEME, METATAAL, KOLLOKASIES, POËME, SITATE, ADVISEURS, RASSISTIESE LEKSIKALE ITEMS, NEUTRALE LEMMAS, ELEKTRONIESE MANUSKRIP, VERWYSINGS, SEMANTIESE OPPOSISIE, SEKSISMES, GESTIGMATISEERDE SEKSUELE VERSKYNSELS, GESTIGMATISEERDE FISIEKE TOETSTANDE, GESTIGMATISEERDE GEESTELIKE TOESTANDE, POLITIEKE ITEMS, GODSDIENSTIGE ITEMS, PLAT LEKSIKALE ITEMS, VULGÊRE LEKSIKALE ITEMS, SKELTAAL, VLOEKWOORDE

\section{Inleiding}

Wanneer dit oor die hantering van beledigende en sensitiewe leksikale items in die WAT gaan, is dit die uitgangspunt van die Buro van die WAT om sy ideaal van omvattendheid na te streef, maar om terselfdertyd 'n sensitiewe hante- 
ringsbeleid te volg. Hierdie sensitiwiteit moet ook uit die metataal van die WAT blyk.

Die Buro se strewe na omvattendheid geld sowel die makro- as die mikrostruktuur van die WAT. Wat die makrostruktuur betref, slaan omvattendheid op die hoeveelheid en verskeidenheid van die leksikale items wat in die woordeboek opgeneem word vir behandeling; wat die mikrostruktuur betref, slaan omvattendheid op die hoeveelheid en verskeidenheid van die verskillende inligtingstipes wat binne die artikels aangebied word.

Omvattendheid in die makro- en mikrostruktuur is ' $n$ relatiewe begrip. Ten opsigte van die makrostruktuur is geen woordeboek volkome omvattend in die opname van leksikale items nie. ' $n$ Woordeboek kan dit hoogstens met betrekking tot die verteenwoordigendheid van die verskillende soorte taaluitinge wees. Die digtheid van opname in die onderskeie kategorieë in 'n bepaalde woordeboek en tussen ooreenstemmende kategorieë in verskillende woordeboeke kan wyd uiteenlopend wees. Woordeboeke gaan byvoorbeeld dikwels kompromieë met betrekking tot die volledigheid van opname van tegniese taalgebruik aan. As rede hiervoor word gewoonlik die feit aangegee dat tegniese taalgebruik 'n beperkte gebruiksfrekwensie het. Ten opsigte van die mikrostruktuur verskil die meeste omvattende woordeboeke ook wat die verskeidenheid van inligtingstipes en die relatiewe digtheid van hulle aanbieding betref. In sy beleidstelling het die Buro gevolglik in gedagte gehou dat die WAT nooit in alle opsigte volkome omvattend kan wees nie.

Taalgebruik kan dermate beledigend wees dat dit die sosiale struktuur van die taalgebruikers ernstig aantas. Sodanige taalgebruik kan voorts lei tot 'n distansiëring van nie alleen produkte van die taal nie, maar ook van die taal self.

By die internasionale kongres oor die hantering van beledigende en sensitiewe leksikale items in die WAT (Stellenbosch, 8 - 10 Febr. 1994) wys prof. Vernon February op 'n essensiële kenmerk van rassismes wat dit van ander beledigende terme, byvoorbeeld vloekwoorde, onderskei. 'n Rassistiese term verwys byna uitsluitlik na 'n eienskap wat op geen wyse ophefbaar is nie. Dit word gebruik om 'n bepaalde fisieke eienskap of gewaande karaktertrek van die benoemde aan te dui. Niemand kan byvoorbeeld sy etniese afkoms ophef nie. As jy iemand oor sy etniese afkoms spot of hom daarmee beledig, tref jy hom in iets waaraan hy niks kan doen nie.

Ofskoon die graad van kwetsendheid van beledigende leksikale items in die eerste plek bepaal word deur hulle betekenis en in die tweede plek deur die sosiale houdings wat tot hulle aanwending aanleiding gee, beleef diegene op wie rassistiese terme gerig is sulke terme juis weens die genoemde eienskap van onophefbaarheid as uiters kwetsend.

Die eienskap van onophefbaarheid speel dikwels ook ' $n$ rol in die ander kategorieë van beledigende leksikale items wat hier ter sprake is. Voorbeelde hiervan is onder andere seksismes, leksikale items wat gestigmatiseerde fisieke of geestelike toestande en verskynsels by die mens aandui, en godsdienstig 
sensitiewe leksikale items. Vergelyk in dié verband vrouelis, mannemoed, oumansklier, mongool, idioot, vertraag, psigopaat, haaslip, horrelvoet, boggel, skeel, moffie, poefter, trassie, Katools, soos 'n Katoliek bid, Mohammedaan. In hierdie kategorieë is die eienskap van onophefbaarheid egter nie absoluut nie; daar kom sowel algehele uitsonderings as graduele verskille tussen en binne die meeste van die kategorieë voor. In gevalle waar onophefbaarheid egter wel soos by rassismes 'n rol speel, word sulke krenkende verwysings insgelyks as besonder kwetsend aangevoel.

Daarenteen verwys die meeste leksikale items wat binne ' $n$ bepaalde politieke of sosiale struktuur as sensitief ervaar word in 'n wisselende mate na iets wat ophefbaar is. Vergelyk in dié verband agtergeblewene, armlastige, plakker, bloubaadjie (verkeerskonstabel), hond (polisieman), platpoot, terroris, vryheidsvegter, comrade. Ook sulke leksikale items kan beledigend, kwetsend of distansiërend aangewend word; hier word egter groter graduele verskille in hulle belewing waargeneem.

In Suid-Afrika heers daar 'n besonder sensitiewe klimaat wat die gebruik van rassistiese leksikale items betref. By die gemelde internasionale kongres is die vermoede uitgespreek dat hierdie klimaat van verbygaande aard is. Daar is in daardie stadium nietemin gevoel - weliswaar nie deur almal nie - dat die opname van rassistiese leksikale items in die WAT in hierdie periode van versoening ongewens sou wees. Dit sal nie alleen versoening strem nie, maar in sekere kringe ook groter verwydering veroorsaak.

Die Buro van die WAT wil in sy strewe na omvattendheid nie aandadig wees aan die vestiging of bestendiging van rassistiese leksikale items deur die opname daarvan in die WAT nie, maar hy het wel 'n verantwoordelikheid om gebruikers te waarsku teen die rassistiese aard van sekere leksikale items. Dit kan hy slegs doen as hy hierdie leksikale items identifiseer en op een of ander wyse onder die aandag van die gebruiker bring.

Eweneens wil die Buro nie die gebruik van seksistiese leksikale items of leksikale items waarmee op 'n beledigende of onsensitiewe wyse na gestigmatiseerde fisieke of geestelike toestande en verskynsels by die mens verwys word, aanmoedig nie; hy het wel die plig om hulle te identifiseer en die gebruiker teen die krenkende aard daarvan te waarsku.

Wat die opnamebeleid vir die leksikograaf kompliseer, is die feit dat daar - soos reeds aangedui - graduele verskille aangetref word nie net tussen verskillende kategorieë beledigende of sensitiewe leksikale items nie, maar ook binne een en dieselfde kategorie. Selfs nie alle rassistiese taal word byvoorbeeld as ewe negatief aangevoel nie. 'n Simpleks soos kaffer word as besonder rassisties ervaar, terwyl 'n kompositum met 'n rassistiese komponent nie noodwendig as erg rassisties ervaar hoef te word nie. 'n Kompositum soos kafferbrak is volledig rassisties, terwyl 'n term soos kafferwaatlemoen relatief minder rassisties is. 'n Uitdrukking soos alle kaffers het swart velle (swartes is onbetroubaar), waarmee rasverskille aangewend word om iemand te beledig, word as uiters rassisties aangevoel. 
In die hantering van beledigende en sensitiewe taal moet daar rekening gehou word met die genoemde verskille tussen rassismes, seksistiese taal en taal waarmee gestigmatiseerde fisieke of geestelike toestande en verskynsels by die mens, of godsdienstige, politieke en sosiale verskille benoem word. Ook moet daar tussen verskillende tipes binne elk van hierdie kategorieë onderskei word.

Teen dié agtergrond het die Buro 'n voorlopige beleid vir die bewerking van beledigende en sensitiewe leksikale items in die WAT geformuleer en aan sowel al die deelnemers aan die genoemde kongres as taalgebruikers, taalpraktisyns, taalkundiges en ander belangrike internasionale leksikograwe en metaleksikograwe gestuur vir kommentaar. In wese het die beleid van die volgende argument uitgegaan:

Aangesien die WAT nooit in alle opsigte volkome omvattend kan wees nie en aangesien tegniese taal sonder verontwaardiging of teëspraak ' $n$ uitsondering op die strewe na omvattendheid vorm, kan geredeneer word dat daar des te meer ' $n$ uitsondering gemaak behoort te word ten opsigte van taal wat as uiters kwetsend ervaar word en wat net soos tegniese taal - maar weliswaar om ander redes - gewoonlik 'n beperkte gebruiksfrekwensie het. Gevolglik is voorgestel dat geen rassistiese leksikale items in die gedrukte WAT verklaar en, op ' $n$ enkele uitsondering na, geen rassistiese komposita daarin opgeneem word nie. Simplekse van dié aard word wel opgeneem, maar bloot met 'n verwysing na die volledige behandeling in elektroniese vorm wat op aanvraag beskikbaar sal wees. Besonderhede oor sowel hierdie simplekse as hulle komposita is dan hier te vind.

Die Buro het uiteenlopende reaksie op hierdie beleid ontvang. Dit het gewissel van goedkeuring tot voorwaardelike goedkeuring tot ernstige kritiek.

Die belangrikste kritiek was:

(a) Die Buro mag nie nou inligting weerhou of selfsensuur toepas waar die land wegbeweeg van 'n politieke sisteem wat juis vir die weerhouding van inligting gekritiseer is nie.

(b) In die gedrukte weergawe van die WAT gee die Buro ' $n$ valse beeld van die werklikheid en maak hom veral ten opsigte van die hantering van rassismes skuldig aan geskiedsvervalsing.

(c) Dit is die plig van 'n omvattende woordeboek soos die WAT om alle soorte leksikale items op te neem, te verklaar en van gebruiksinligting te voorsien.

(d) Die koper van 'n gesensureerde WAT sal lewenslank tot 'n woordeboek met onvolledige inligting verbind wees.

(e) Die elektroniese weergawe is nie toeganklik genoeg nie en kan nie op dieselfde permanensie as die boek aanspraak maak nie.

(f) Die toepassing van die beleid bring 'n opvallende diskrepansie in die hanteringswyse van verskillende soorte leksikale items mee. 
(g) Die beleid is 'n oorreaksie op 'n probleem wat wêreldwyd voorkom maar hier te lande verpolitiseer is en gevolglik grootliks weer sal oorwaai.

(h) Oor 'n honderd jaar sal die WAT se beleid waarskynlik net so belaglik voorkom soos die Victoriaanse preutsheidsreëls.

Die Buro meen by nabetragting dat dit waarskynlik nie 'n geldige argument in sy konsepbeleid was om die onvolledigheid van woordeboeke ten opsigte van tegniese taal as motivering vir die weglating van rassistiese leksikale items te gebruik nie. Daar is in dié verband 'n geldige verskil tussen die tegniese en die rassistiese geaardheid van leksikale items: Hoogs gevorderde vaktaal kan niemand krenk nie; daarom hoef niemand teen die gebruik daarvan gewaarsku te word nie. Rassismes is altyd krenkend; daarom behoort woordeboekgebruikers wel teen hulle gebruik gewaarsku te word. Rassismes en ander beledigende en sensitiewe leksikale items kan dus minder geredelik as hoogs gevorderde vaktaal uit 'n omvattende woordeboek soos die WAT weggelaat word. By beledigende en sensitiewe leksikale items is makrostrukturele omvattendheid gevolglik uiters belangrik. Dit maak dit moontlik om elke sodanige lemma na behore te etiketteer.

Die Buro is egter van opinie dat mikrostrukturele omvattendheid by rassismes en ander beledigende en sensitiewe leksikale items nie so streng nagestreef hoef te word nie, solank betekenisverklaring plaasvind en die gebruiker teen die kwetsende aard van die items gewaarsku word.

In die lig van laasgenoemde opinie en van die kritiek wat op die eerste weergawe van sy beleid ontvang is, asook van die positief veranderende sosiale verhoudings in Suid-Afrika (soos hier onder nader aangedui word), het die Buro ' $n$ alternatiewe beleid vir die hantering van beledigende en sensitiewe leksikale items daargestel. Die beleid kom hoofsaaklik daarop neer dat al sulke leksikale items in die gedrukte WAT opgeneem, geëtiketteer en verklaar word maar dat geen kollokasies en poëme daarby aangegee word nie. By rassismes, maar nie by die ander soorte beledigende en sensitiewe leksikale items nie, word ook geen kwetsende sinonieme, geen semantiese opposisies, verwysings en sitate of ander gebruiksvoorbeelde opgeneem nie. Hierdie ontbrekende inligting, met uitsondering van kollokasies en poëme asook van alle sitate wat 'n negatiewe houding teenoor enige bevolkingsgroep weerspieël, word wel volledig in 'n elektroniese weergawe opgeneem. In dié vorm kan dit aan gebruikers beskikbaar gestel word.

Sedert die aanbieding van die genoemde internasionale kongres het SuidAfrika reeds ' $n$ jaar van demokrasie beleef en het daar in die land 'n proses van herbesinning en politieke sowel as sosiale katarsis op dreef gekom. Die meeste mense wat deur die misstande van die verlede benadeel is, het hulle vernedering, pyn, protes, woede en hartseer op persoonlike vlak of in die openbaar begin verwoord. Net so is daar van die ander kant reeds skuld en spyt oor aangedane leed uitgespreek en gedemonstreer. By die gemelde internasionale 
kongres op Stellenbosch was daar ook al tekens van hierdie proses. 'n Verblydende gees van vergifnis en versoening het op grond van hierdie ontwikkelinge in die demokratiese Suid-Afrika posgevat. Dit is veral aangevuur deur die gevoel van bevryding sedert die verkiesing van 27 April 1994 en deur die wydverspreide vertroue in die oorgangsregering van die land.

In hierdie gees van versoening is daar ook van verskeie kante op die konsepweergawe van die Buro se Beleid vir die hantering van beledigende en sensitiewe leksikale items in die Woordeboek van die Afrikaanse Taal (WAT) gereageer. Alhoewel die Buro nie namens ander en veral nie namens diegene kan praat wat ten seerste onder die ou bedeling van diskriminerende rasseskeiding en vernedering gely het nie, het hy tog die gevoel by die internasionale kongres, uit latere gesprekke met akademiese, politieke en gemeenskapsleiers, asook uit die ontvange kommentaar gekry dat die kongres, die opvolggesprekke en die gemelde meer versoenende gees in 'n groot mate die geleentheid vir ontlading en herbesinning gebring het. Dit lyk of die hewigheid in die belewing van veral rassismes reeds na een jaar van nuwe landsregering aan die afneem is en bykans op dieselfde sensitiwiteitsvlak lê as tale wat nie soos Afrikaans deur politieke en sosiale spanning geaffekteer is nie. Dit wil voorkom of dié versoenende gees in toenemende mate by alle lae van die bevolking begin posvat.

Verder moet in gedagte gehou word dat die hewige reaksies op die WAT ontlok is deur die growwe rassismes en ander beledigende materiaal wat in die ouer dele daarvan aangetref word. Die reaksies was reeds nie meer so negatief op die hantering van beledigende en sensitiewe materiaal in die jongste WAT nie. Daar kan dus aanvaar word dat die hier onder voorgestelde hantering van sulke items ' $n$ veel minder heftige of glad geen reaksie nie sal ontlok.

Teen dié agtergrond en met inagneming van alle ontvange kommentaar is die onderstaande beleid geformuleer.

\section{A. Rassismes}

Voorbeelde: aia, Asiaat, Boesman, Hottentot, kaffer, Kleurling, koelie, bitterbek (bruin of swart mense), hotnot (bruin mens), Kaaskop (Nederlander), Rooinek (Engelsman), witvel (blanke persoon), zool (swart mens), hotnotsblymaak (ligte reëntiie wat met kort onderbrekings val), Kafferafrikaans (krom Afrikaans soos gebruik deur sommige swart mense), koeliegriep (Oosterse griep), meidewerk, witmanstaal, hotnotskooigoed (sagte, vaal, wollerige kruidgewas), kafferblom (poinsettia), kakiebos (enigeen van enkele onkruidsoorte), boesmanrys (termietlarwes), hottentotsgot (verskillende soorte vleisetende insekte van die familie Mantidae), kafferkraai (boskraai), Boesmanland, Hotnotsbaai, Kafferberg, Meidekop (geografiese name wat in die metataal kan aanstoot gee), Boere (Afrikaners; die polisie; gevangenisbewaarders), Franse siekte (sifilis), Jood (suinige, inhalige persoon; 'n sluwe sakeman; 'n woekeraar), Spanjools, ' $n$ Boesmantjie doodslaan 
(sleg slaap; 'n drankie geniet; rusteloos, haastig wees), los hotnot (iemand sonder werkverpligtings, wat vry is om te kom en te gaan soos hy wil; 'n (gras)wewenaar of -weduwee), koelietaal vir iemand wees (onverstaanbaar vir hom wees).

\section{Hantering in die WAT}

Die begrip "rassisme" moet duidelik in die Toeligting van elke WAT-deel omskryf word. Rassistiese leksikale items sal slegs vir opname oorweeg word indien hulle aan die algemene gebruiklikheidskriterium van die Buro voldoen.

Daar word onderskei tussen volledig rassistiese leksikale items en gedeeltelik rassistiese leksikale items. Volledig rassistiese leksikale items is simplekse soos hotnot en kaffer en komposita soos hotnotstaal, kafferbrak en uitkaffer waarvan al die betekenisonderskeidings rassisties is. Gedeeltelik rassistiese leksikale items is polisemiese terme soos boer en meidjie waarby neutrale betekenisonderskeidings voorkom. Die term boer beteken byvoorbeeld in die eerste plek ook "iem. wat boer", terwyl meidjie as vertederende aanspreekvorm vir vroulike persone gebruik word. Dit geld ook polisemiese komposita waarvan die komponente self nie rassisties is nie, maar die geheel wel, byvoorbeeld gifasem en houtkop.

(a) Volledig rassistiese leksikale items

Alle simplekse, komposita en uitdrukkings word gelemmatiseer en met inagneming van onderstaande verdere voorwaardes bewerk.

Lemmas word soos volg geëtiketteer: rassisties; die gebruik hiervan is uiters neerhalend en aanstootlik. Die etiket word duidelik in die Toeligting omskryt.

Die metataal is so neutraal en sensitief as moontlik.

In die metataal word ook sensitief omgegaan met terme wat na alle waarskynlikheid in die toekoms nie 'n neutrale waarde vir taalgebruikers sal hê nie, byvoorbeeld inboorling. Dit sou beter wees om in dié geval 'n term soos outogtoon of 'n omskrywing soos "inheemse bewoner van ..." te gebruik.

'n Rassistiese leksikale item word, waar daar een of meer neutrale sinonieme bestaan, na die enigste of die gebruiklikste sinoniem vir die definisie verwys, ongeag die gebruiklikheid van die rassistiese leksikale item wat verwys word. Geen rassistiese sinonieme word egter by 'n neutrale of 'n rassistiese leksikale item vermeld nie.

Geen semantiese opposisies, byvoorbeeld antonieme, word gegee nie.

Geen voorbeeldmateriaal, m.a.w. kollokasies, poëme of sitate, word aangegee nie. Die Buro wil geen enkoderende inligting oor rassistiese leksikale items in die gedrukte WAT verstrek nie. 
- Uitdrukkings met hierdie leksikale items word opgeneem en verklaar, maar geen rassistiese of neutrale sinonieme, antonieme of verwysings na ander leksikale items in die WAT en geen voorbeeldmateriaal word daarby aangegee nie. Die uitdrukking ' $n$ los hotnot sal byvoorbeeld in die artikel van die lemma los en die uitdrukking koelietaal vir iemand wees sal in die artikel van die lemma koelietaal opgeneem en op die aangeduide beperkte wyse bewerk word.

- Dieselfde hanteringswyse geld rassistiese uitdrukkings onder 'n neutrale lemma, m.a.w. uitdrukkings waarvan nie een van die komponente rassisties is nie, maar die geheel wel (vgl. kort voor die stroois omgedraai hê, met die betekenis "van gemengde bloed wees").

- Vir ' $n$ volledige bewerking van die betrokke lemma - met insluiting van uitdrukkings daarmee - of van 'n rassistiese uitdrukking onder 'n neutrale lemma word die gebruiker in die Toeligting verwys na die elektroniese manuskrip van die Buro wat op aanvraag in elektroniese vorm beskikbaar is. Die volgende formulering kan daarvoor gebruik word: "Raadpleeg die Buro se elektroniese manuskrip vir 'n volledige bewerking van hierdie leksikale item". By die rassistiese lemma of uitdrukking word die gebruiker na die Toeligting verwys.

(b) Gedeeltelik rassistiese leksikale items

Alle simplekse, komposita en uitdrukkings word gelemmatiseer en met inagneming van onderstaande verdere voorwaardes bewerk.

By neutrale betekenisonderskeidings word ' $n$ volledige bewerking gedoen.

- Rassistiese betekenisonderskeidings en uitdrukkings word met die etiket rassisties; die gebruik hiervan is uiters neerhalend en aanstootlik gemerk en verder presies soos volledig rassistiese leksikale items onder (a) hier bo gehanteer.

Die Buro van die WAT behou hom die reg voor om na oorlegpleging en namate die klimaat ten opsigte van die belewing van rassismes verander, die beleid oor die hantering van rassismes te hersien. As die belewenis van sensitiewe taal met verloop van tyd minder traumaties sou word, sou dit miskien moontlik kon wees om op 'n meer kliniese wyse na rassismes te kyk. Veral samestellings met termstatus, soos kafferwaatlemoen, hottentotsgot, boesmaniys en meidebossie, wat in vergelyking met simplekse en uitdrukkings as minder rassisties ervaar word, sou byvoorbeeld in ' $n$ latere stadium heroorweeg kon word vir ' $n$ meer volledige bewerking wat die aangawe van sinonieme, antonieme, verwysings en gebruiksvoorbeelde in die vorm van sitate betref. 
2. Hantering in die elektroniese manuskrip

Alle rassistiese leksikale items wat in afgeskaalde vorm in die gedrukte weergawe van die WAT opgeneem is, word met inagneming van onderstaande verdere voorwaardes meer volledig in die elektroniese weergawe bewerk en vir beskikbaarstelling in elektroniese vorm geberg.

Die etikettering van hierdie leksikale items geskied sorgvuldig en sensitief. Daar word ruimte gelaat vir die moontlikheid om graduele verskille (vgl. meidebossie, meid en soos ' $n$ meid lag) in die rassistiese aard van die leksikale item of betekenisonderskeiding aan te dui. Die etikette wat gebruik word om sodanige gradering aan te toon, word in die Toeligting verklaar.

- Die metataal is so neutraal en sensitief as moontlik en leksikale items wat na alle waarskynlikheid in die toekoms nie 'n neutrale waarde vir taalgebruikers sal hê nie, byvoorbeeld inboorling, word in die metataal vermy.

- Verwysings na of vermeldings van sinonieme of semantiese opposisies word by sowel die neutrale as nieneutrale leksikale items gegee.

- Kollokasies en poëme word nie opgeneem nie.

- Gebruiksvoorbeelde in die vorm van sitate word gegee maar versigtig gekies. Geen sitate word opgeneem waarin rassismes gebruik word om 'n negatiewe houding teenoor enige bevolkingsgroep uit te spreek nie. Iets soos ' $n$ Mens kan nie ' $n$ kaffer met die bouwerk vertrou nie is nie as toeligtingsmateriaal aanvaarbaar nie. Ook word geen sitate opgeneem waarin die verskynsel, die toepassing of die gevolge van rassisme goedkeurend bejeën word nie.

- Die inhoud van die elektroniese manuskrip sal op aanvraag ooreenkomstig die Buro se geldende beleid beskikbaar wees.

Artikels van rassistiese leksikale items in sowel die gedrukte WAT as die elektroniese manuskrip word deur adviseurs van die Buro gekontroleer ten opsigte van korrektheid en sensitiewe hantering.

\section{B. Seksismes en sensitiewe leksikale items wat gestigmatiseerde sek-} suele verskynsels, praktyke en voorkeure by die mens aandui

Voorbeelde: vrouelis, verwyf, ouvroustories, oujongnooi, swakker vat, mannemoed, oumansklier, oujongkêrel, gigolo (man wat deur 'n vrou onderhou word), hoer, snol, agtermekaarkêrel, haas, kween, manvrou, moffie, poefter, sodomieter, trassie.

Hierdie kategorie word ruim opgevat aangesien nie alle sensitiewe leksikale items hierin kwetsend vir 'n bepaalde geslag is of iemand in sy of haar geslagtelikheid krenk nie.

Die Buro wil geen geslagtelik diskriminerende hiërargie kontinueer of bestendig nie, maar eerder 'n rol speel in die gelykberegtiging van geslagte. Ook wil hy neutraal staan teenoor verskillende seksuele verskynsels, oriënta- 
sies, praktyke en voorkeure. In die lig hiervan word die volgende hanteringsbeleid gevolg:

Seksistiese leksikale items sal slegs vir opname oorweeg word indien hulle aan die algemene gebruiklikheidskriterium van die Buro voldoen.

Alle seksistiese leksikale items wat aan dié voorwaarde voldoen, word opgeneem en met inagneming van onderstaande verdere voorwaardes

volledig bewerk.

In die metataal word sensitief omgegaan met terme wat as seksisties ervaar word, of na alle waarskynlikheid in die toekoms as sodanig gevoel sal word.

Gemeenslagtige of neutrale voornaamwoorde en ander verwysings word in die metataal gebruik. 'n Herhaling van hy/sy of hom/haar word in die algemeen deur die leser as steurend ervaar. Daarom word formulerings soos die volgende aanbeveel: "Iem. wat ...", "Persoon wat ...", "T.o.v. volwassenes" (i.p.v. "T.o.v. 'n man of vrou"), "T.o.v. kinders" (i.p.v. "T.o.v. seuns en meisies"), of "T.o.v. mense", ens.

- Geslagtelik kwetsende lemmas word duidelik as seksisties geëtiketteer en die etiket word in die Toeligting van elke WAT-deel omskryf.

- Die definisie word waar moontlik, ongeag die gebruiklikheid van die nieneutrale leksikale item, by die gebruiklikste neutrale sinoniem aangegee. By vrygesel sal dus 'n deskriptiewe definisie kom, terwyl oujongkêrel na vrygesel verwys word. Net so kom daar 'n deskriptiewe definisie by homoseksueel; terwyl moffie verklaar word met manlike homoseksueel, wat 'n indirekte verwysing na ' $n$ sinoniem bevat.

- Verwysing van die kwetsende na die neutrale sinoniem, en omgekeerd, vind volledig plaas. Oujongkêrel sal dus na vrygesel verwys word, en andersom. Elke geslagtelik kwetsende sinoniem by 'n neutrale lemma word duidelik op die betrokke plek as seksisties geëtiketteer. Ook antonieme en ander verwysings word gegee.

- Kollokasies en poëme word nie opgeneem nie. gekies. Geen sitate word opgeneem waarin 'n seksistiese benaming gebruik word om 'n negatiewe houding teenoor 'n bepaalde geslag te openbaar nie. Iets soos Geen man sal na 'n tipiese oujongnooi kyk nie is nie aanvaarbaar nie. Ook word geen sitate opgeneem waarin die verskynsel, die toepassing of die gevolge van seksisme goedkeurend bejeën word nie. In die keuse van voorbeeldmateriaal word daar gestreef na 'n balans tussen sitate waarin manlike en sitate waarin vroulike rolspelers voorkom. Hierdie bepalinge geld ook sitate in artikels van neutrale lemmas.

- Uitdrukkings met 'n seksistiese leksikale item, byvoorbeeld soos 'n viswyf skel, word op die normale wyse opgeneem en bewerk, behalwe dat ook hier geen kollokasies en poëme gegee word nie. 
Ten einde nie deur verswyging te diskrimineer teen enige geslag of teen verskillende seksuele voorkeure nie, byvoorbeeld deur bepaalde leksikale items te ignoreer op grond van 'n seksistiese oorweging of omdat hulle aan ander groepe aanstoot kan gee, sal alle soorte literatuur op 'n nog meer verteenwoordigende wyse vir ook sulke materiaal geëkserpeer word. Op dié manier hoop die Buro om 'n korrekte en gebalanseerde beeld daarvan te gee.

Artikels van leksikale items in hierdie kategorie word deur adviseurs van die Buro gekontroleer ten opsigte van korrektheid en sensitiewe hantering.

C. Sensitiewe leksikale items wat gestigmatiseerde fisieke of geestelike toestande en verskynsels by die mens aandui

Voorbeelde: gebreklik, gestrem, tartie (afgelei van Engels "retarded"), kinderverlamming, haaslip, boggel, horrelvoet, skeel, blind, doof, doofstom, hardhorend, swaksiende, stokblind, stokdoof, doof soos 'n kwartel, kruppel, lam, melaats, mongool, idioot, eenvoudig van gees, geestelik versteurd, sielsiek, vertraag, mal, kranksinnig, psigopaat, waterhoof.

Ofskoon die eienskap van onophefbaarheid op die meeste van die sensitiewe leksikale items in hierdie kategorie van toepassing is, word hulle tog nie so kwetsend soos rassismes ervaar nie omdat hulle op 'n mindere skaal gebruik word om die benoemdes doelbewus te beledig. Verwysing speel hier ' $n$ groter rol as tipering en belediging. Met diê onderskeid in gedagte word die volgende hanteringswyses gevolg:

- Sensitiewe leksikale items in hierdie kategorie sal slegs vir opname oorweeg word indien hulle aan die algemene gebruiklikheidskriterium van die Buro voldoen.

- Alle leksikale items wat aan dié voorwaarde voldoen, word opgeneem en met inagneming van onderstaande verdere voorwaardes volledig bewerk.

- Volledige bewerking sluit die aangee van sinonieme, antonieme en ander verwysings in. Verwysing van die kwetsende na die neutrale sinoniem, en omgekeerd, vind dus plaas. Elke kwetsende sinoniem by ' $n$ neutrale lemma word op die betrokke plek van sy toepaslike etiket voorsien.

- Sensitiewe leksikale items word met groot omsigtigheid in die metataal gebruik.

Nieneutrale leksikale items word geëtiketteer. Hierdie etikette word duidelik in die Toeligting van elke WAT-deel verklaar. 
- Die definisie word waar moontlik, ongeag die gebruiklikheid van die nieneutrale leksikale item, by die gebruiklikste neutrale sinoniem aangegee. Haaslip sal byvoorbeeld na gesplete lip en mongolisme na Downsindroom verwys word. Indien daar nie 'n neutrale sinoniem bestaan nie, word die nieneutrale leksikale item volledig bewerk.

- Wat sensitiewe leksikale items soos haaslip, horrelvoet, doof en blind betref, is daar graduele verskille. Indien iemand werklik blind is, kan die benoeming blind as redelik neutraal beskou word. Waar iemand se sig enigsins aangetas is, sal blind nie alleen as 'n verkeerde benoeming nie maar ook as krenkend ervaar word. Dieselfde geld ook doof $x$ hardhorend. Daar moet daarteen gewaak word om nie ' $n$ betekenisonderskeiding op te neem wat die feitelike gegewens verdraai nie. By die lemma blind sal per etiket aangedui word dat dit in sommige gevalle deur die benoemdes as krenkend ervaar kan word.

Graduele verskille kom nie alleen tussen betekenisonderskeidings binne een artikel (byvoorbeeld van blind) voor nie, maar ook tussen verskillende leksikale items. Daarom behoort haaslip 'n sterker veroordelende etiket as byvoorbeeld horrelvoet te kry. Haaslip is besonder krenkend omdat ' $n$ menslike eienskap met dié van ' $n$ dier in verband gebring word. Dieselfde geld van leksikale items waarin van ' $n$ intensivering gebruik gemaak word. So is stokblind meer krenkend as blind en so doof soos ' $n$ kwartel meer krenkend as doof. In laasgenoemde is daar selfs ' $n$ stapeling van krenkendhede: nie net vind intensivering deur vergelyking plaas nie maar hierdie vergelyking is boonop met ' $n$ dierlike eienskap. Al hierdie verskille speel ' $n$ rol by die graduele onderskeiding met behulp van etikette.

Kollokasies en poëme word nie opgeneem nie.

Gebruiksvoorbeelde in die vorm van sitate word gegee maar versigtig gekies. Geen sitate word opgeneem waarin 'n kwetsende benaming van hierdie aard gebruik word om 'n negatiewe houding teenoor mense uit te spreek by wie gestigmatiseerde fisieke of geestelike toestande en verskynsels voorkom nie. Iets soos Weens hulle onselfstandigheid is die blindes ' $n$ las op die samelewing is nie aanhaalbaar nie. Ook word geen sitate opgeneem waarin diskriminasie op hierdie terrein goedkeurend bejeën word nie.

Uitdrukkings waarin leksikale items voorkom wat op gestigmatiseerde fisieke of geestelike toestande en verskynsels by die mens dui, word met sterk veroordelende etikette gemerk. Die genoemde uitdrukkings (vgl. blind soos ' $n$ mol en melaats wees) word volledig bewerk.

Artikels van leksikale items in hierdie kategorie word deur adviseurs van die Buro gekontroleer ten opsigte van korrektheid en sensitiewe hantering. 


\section{Sensitiewe leksikale items binne 'n sosiale, politieke en godsdienstige struktuur}

Voorbeelde: armlastige, agtergeblewene, minderbevoorregte, onderontwikkelde, plakker, lokasie, bloubaadjie (verkeerskonstabel), hond (polisieman), platpote (polisieman), kapitalis, kommunis, civics, comrade, demand, toi-toi, regime, struggle, terroris, vryheidsvegter, Dopper, Gatjieponner, heppiekleppie, Katools, soos 'n Katoliek bid, dogterkerk, sektekerk, Gam, Mohammedaan, Moslem (in plaas van Moesliem), Slams, soos in 'n Jodekerk wees (lawaaierig).

Al die leksikale items in hierdie kategorie, ook dié wat iets te kenne gee wat ophefbaar is, kan beledigend, kwetsend of distansiërend aangewend of ervaar word. Vergelyk in dié verband agtergeblewene, armlastige, plakker, regime, platpote, terroris. Die graad van vernedering is nie by elke leksikale item dieselfde nie en ook nie altyd voorspelbaar nie. Die volgende hanteringsbeleid word gevolg:

- Sensitiewe leksikale items in hierdie kategorie sal slegs vir opname oorweeg word indien hulle aan die algemene gebruiklikheidskriterium van die Buro voldoen.

- Alle leksikale items wat aan dié voorwaarde voldoen, word opgeneem en met inagneming van onderstaande verdere voorwaardes volledig bewerk.

Volledige bewerking sluit die aangee van sinonieme, antonieme en ander verwysings in. Verwysings van die kwetsende na die neutrale sinoniem, en omgekeerd, word byvoorbeeld volledig gegee. Elke kwetsende sinoniem by 'n neutrale lemma word op die betrokke plek van sy toepaslike etiket voorsien.

- Hierdie leksikale items word sover moontlik nie in die metataal gebruik nie. Verder word leksikale items wat tans, of na alle waarskynlikheid in die toekoms, nie 'n neutrale waarde vir taalgebnuikers sal hê nie, ten alle koste in die metataal vermy.

- Toepaslike etikette dui die sensitiewe aard van uiteenlopende gevalle aan, byvoorbeeld regime, platpoot en bloubaadjie (neerhalend) teenoor struggle, demand en comrade (in bepaalde politieke kringe as distansiërend ervaar). Hierdie etikette word in die Toeligting van elke WAT-deel verklaar.

- Kollokasies en poëme word nie opgeneem nie.

Gebruiksvoorbeelde in die vorm van sitate word gegee maar versigtig gekies. Geen sitate word gebruik waarin sosiale of politieke groeperinge, gelowe of geloofsgenootskappe aanstoot gegee word nie. Iets soos Die plakkers het vanweë ontoereikende behuising baie koud gekry toe die Kaapse winter toegeslaan het is aanvaarbaar, maar Die plakkers van Crossroads leef soos diere in krotte is dit nie. Ook word geen sitate opgeneem waarin misstande ten gevolge van ' $n$ bepaalde sosiale of politieke struktuur goedkeurend bejeën word nie. 
- Ten einde nie deur verswyging teen veral verskillende politieke en geloofsgroepe te diskrimineer nie, byvoorbeeld deur hulle taaluitinge te verswyg op grond van ideologiese of teologiese apatie of omdat bepaalde leksikale items aanstoot aan ander groepe kan gee, sal alle soorte literatuur op 'n nog meer verteenwoordigende wyse vir ook sulke materiaal geëkserpeer word. Op dié manier hoop die Buro om 'n korrekte en gebalanseerde beeld daarvan te gee. Dit geld veral woorde soos comrade, toi-toi, struggle en vryheidsvegter.

- Artikels van leksikale items in hierdie kategorie word deur eksterne adviseurs van die Buro gekontroleer vir korrektheid en sensitiewe hantering. Artikels van sensitiewe leksikale items op politieke en godsdienstige terrein word vir dieselfde doel aan kundige en erkende verteenwoordigers van politieke groepe en geloofsgenootskappe voorgelê.

\section{E. Plat en vulgêre leksikale items, skeltaal en vloeke}

Voorbeelde: bedonderd, fok (ook as vloek), fokken, kakpraat, opdonder, opneuk, opmoer, naai, pis, skyt, stront (ook as skeltaal en vloek), esel (as skeltaal), hond (as skeltaal), vark (as skeltaal), moerskont, verdomp, vuilgoed (as skeltaal), allemagtig (as vloek), bliksem (as vloek), hel (as vloek), Here (as vloek).

Al die leksikale items in hierdie kategorie kan aanstoot gee of beledigend en krenkend aangewend of ervaar word. Die graad van kwetsendheid is nie by elke leksikale item dieselfde nie en ook nie altyd voorspelbaar nie. Plat en vulgêre taal val byvoorbeeld nie in elke geselskap of sosiale atmosteer in dieselfde swak smaak nie. By skeltaal en vloeke is die sosiale houding van die gebruiker weer van oorwegende belang. Tog weeg betekenis en konnotasie hier ook swaar. Mense voel byvoorbeeld gewoonlik sterker beledig deur skeltaal waarin hulle met 'n vark vergelyk word as met 'n esel of 'n buffel. By vloeke waarin die Godheid op die naam genoem word, is die toehoorder se geloofshouding en -affiliasie weer van groot belang in die belewing daarvan. Verder speel die eienskap van ophefbaarheid 'n belangrike rol in die benoemde se belewing van skeltaal en vloeke. Die volgende hanteringsbeleid word daarom deur die Buro gevolg:

Sensitiewe leksikale items in hierdie kategorie sal slegs vir opname oorweeg word indien hulle aan die algemene gebruiklikheidskriterium van die Buro voldoen.

Alle leksikale items wat aan dié voorwaarde voldoen, word opgeneem en met inagneming van onderstaande verdere voorwaardes volledig bewerk.

- Volledige bewerking sluit die aangee van sinonieme, antonieme en ander verwysings in. Verwysing van die kwetsende na die neutrale sinoniem, en omgekeerd, vind dus plaas. Elke kwetsende sinoniem by 'n 
neutrale lemma word op die betrokke plek van sy toepaslike etiket voorsien.

- Die sensitiewe leksikale items word geëtiketteer. Hierdie etikette word duidelik in die Toeligting van elke WAT-deel omskryf.

- Die definisie word waar moontlik, ongeag die gebruiklikheid van die nieneutrale leksikale item, by die gebruiklikste neutrale sinoniem aangegee. So sal pis (in sy verskillende woordsoortelike funksies) byvoorbeeld na urine en urineer verwys word. Indien daar nie 'n neutrale sinoniem bestaan nie, word die nieneutrale leksikale item volledig bewerk.

Dié leksikale items word sover moontlik nie in die metataal gebruik nie, behalwe in hulle neutrale waardes, soos by esel, hond, vark, vuilgoed, bliksem, hel, Here.

- Kollokasies en poëme word nie opgeneem nie.

- Gebruiksvoorbeelde in die vorm van sitate word gegee maar versigtig gekies. Geen sitate word gebruik waarin godsdienstige, sosiale of politieke groeperinge aanstoot gegee word nie. Dit geld ook sitate in artikels van neutrale lemmas.

Artikels van sulke leksikale items wat betrekking het op gelowe waarmee die redaksie nie goed bekend is nie, word deur erkende adviseurs uit die betrokke geloofsgenootskappe gekontroleer ten opsigte van korrektheid en sensitiewe hantering.

\section{Slotopmerkings}

Daar is reeds op gewys dat ' $n$ woordeboek nooit volkome omvattend in sy opname van leksikale items kan wees nie; ook, dat die redes daarvoor kan verskil maar dat die resultaat daarvan dieselfde is, naamlik onvolledigheid. Volkome omvattendheid kan dus nooit van 'n woordeboek geëis word nie. Wel kan die eis aan 'n wetenskaplik saamgestelde omvattende verklarende woordeboek soos die WAT gestel word dat dit die tydgenootlike taalgebruik op 'n verteenwoordigende wyse sal opneem en interpreteer (dekodeer). Dit geld ook die opname van rassismes en ander sensitiewe leksikale items.

Hierdie verteenwoordigendheid maak van ' $n$ omvattende verklarende woordeboek 'n spieël van sy tyd. Nooit mag so 'n woordeboek die taal- en sosiale werklikheid deur byvoorbeeld selektiewe opname en valse voorstellings verdraai nie. Die WAT mag en wil nie sy plig as juiste spieël van sy tyd versuim nie, maar hy wil ook nie deur 'n onsensitiewe hanteringswyse van veral rassismes en seksismes bydra tot die versteuring van die sosiale struktuur nie.

Ofskoon omvattende verklarende woordeboeke die taalgebruiker help om aktief met die taal om te gaan, dit wil sê om begrippe te enkodeer, voel die Buro dat dit nie sy taak is om dergelike krenkende leksikale items met dié doel onder die aandag van die woordeboekgebruiker te bring nie. Inteendeel, hy 
voel hom eerder verplig om die gebruiker oor die kwetsendheid daarvan in te lig en om dié items verder bloot op 'n sensitiewe wyse te dekodeer. Die Buro wil hier dus eerder ' $n$ sosiaal normerende rol as ' $n$ sosiaal versteurende rol vertolk. Hy doen dit om die kommunikatiewe gebruik van Afrikaans deur al sy sprekers te bevorder en om sodoende menseverhoudinge in die land te verbe. ter.

Ook die blote opname van beledigende en sensitiewe leksikale items kan in ' $n$ sosiaalpolitieke oorgangstyd, soos tans in Suid-Afrika die geval is, as kwetsend beleef word. Die Buro moet dus 'n fyn balans tussen sy weerspieëlende en sy normerende funksies probeer handhaaf. Dit kan hy ten opsigte van rassismes die beste doen deur slegs die nodigste inligting vir die toereikende dekodering en etikettering van sulke leksikale items in die gedrukte WAT te gee maar dié items omvattend tot elektroniese manuskrip te verwerk. In albei gevalle word daar steeds omsigtig met hierdie materiaal omgegaan. Die manuskrip word dan op aanvraag en ooreenkomstig die Buro se geldende beleid aan bona fide-gebruikers van die WAT beskikbaar gestel. Danksy die moderne tegnologie van die rekenaar en van elektroniese kommunikasiemiddele is die gemelde hanteringswyse reeds vir die Buro uitvoerbaar.

Op hierdie wyse beplan die Buro om 'n argivale rekenaardatabasis van rassistiese taal op te bou. Daardeur wil hy in die eerste plek sy plig as juiste spieël van sy tyd vervul sonder om deur 'n onsensitiewe hanteringswyse van sulke leksikale items by te dra tot die versteuring van die sosiale struktuur. In die tweede plek wil hy verhoed dat hy aan geskiedvervalsing aandadig word.

Samevattend kan die Buro se standpunt onderliggend aan sy beleid soos volg gestel word:

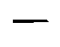

Die Buro streef steeds na omvattendheid in die optekening van die Afrikaanse taalskat.

Die Buro streef steeds daama om sowel die makrostruktuur as die mikrostruktuur van die WAT so omvattend oftewel so verteenwoordigend as moontlik te maak.

Die omvattendheid van die mikrostruktuur hoef nie uitsluitlik uit die gedrukte weergawe van die WAT te blyk nie. Die elektroniese medium kan gevolglik ingespan word om die gedrukte WAT op die terrein van sensitiewe leksikale items aan te vul ten einde 'n verteenwoordigende beeld van Afrikaans te gee.

Die Buro glo dat hy met hierdie beleid vir die hantering van beledigende en sensitiewe leksikale items in die WAT nie alleen begrip openbaar vir 'n probleem wat in die verlede groot pyn, verontwaardiging en tussenmenslike verwydering in Suid-Afrika veroorsaak het nie, maar ook iets doen om die probleem te help regstel sonder om ontrou te raak aan sy opdrag en tipologiese aard. 